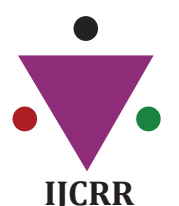

IJCRR

Section: Healthcare

Sci. Journal Impact

Factor: 6.1 (2018)

ICV: 90.90 (2018)

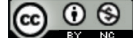

Copyright@IJCRR

\section{Efficacy of Ayurvedic Formulations along with Swedana Therapy in the Management of Amavata (Rheumatoid Arthritis) - A Clinical Study}

\author{
Sonali Dilip Wairagade ${ }^{1}$, Anuja Vasant Nagrare ${ }^{2}$, Tanvi Wairagade ${ }^{3}$, \\ Dhuba Hari Chandi ${ }^{4}$
}

'Associate Professor, Department of Kayachikitsa, Datta Meghe Ayurved Medical College Hospital and Research Centre, Wanadongri, Nagpur, Maharashtra, India; ${ }^{A}$ Associate Professor, Department of Agadtantra, Datta Meghe Ayurved Medical College Hospital and Research Centre, Wanadongri, Nagpur, Maharashtra, India; ${ }^{3}$ MBBS Third year (Major), HBT Medical College and Dr. R N Cooper Hospital, Mumbai, Maharashtra, India; ${ }^{A}$ Assistant Professor, Department of Microbiology, Jawaharlal Nehru Medical College, Datta Meghe Institute of Medical Sciences, Wardha.

\title{
ABSTRACT
}

Amavata is a disease in which vitiation of Vata Dosha and accumulation of Ama take place in joint(s), and it simulates rheumatoid arthritis (RA) at modern phraseology. Shamana (conservative) and Shodhana (biological purification of the body) treatments are advised in Ayurveda whereas anti-inflammatory, analgesics, steroids, and disease modifying antirheumatic drugs are required for its management as per modern medicine, which is not free from side effects.

The symptoms of Amavata are alike to Rheumatism, which include Rheumatoid arthritis and Rheumatic fever. It is observed that Rheumatism is an autoimmune disorder, which is among the collagen disorders having strong and significant parlance with Amavata. A variety of drug trials were already carried out on Amavata, yet there is a lacuna in the management of Amavata. Hence the present study was designed to calculate the effectiveness of Ayurvedic formulations in Amavata.

The study was conducted in 15 clinically diagnosed cases of Amavata (Rheumatoid Arthritis) with objectives of Clinical Evaluation of Therapeutic Effect of Rasnadikashayam 3 t.s.f. thrice/day, Sahachradikashayam 3 t.s.f. once/day, Amvatari Ras 2 tabs once/day were given for 3 months and Erand tail $1 / 2$ t.s.f.once/day at night were given for 1 month along with Swedan therapy in patients of Amavata (Rheumatoid Arthritis) on the basis of various scientific parameters. Patients were treated with the whole therapeutic regime mentioned in Ayurvedic classics i.e., Langhana, Swedana, use of Tikta, Katu, and Deepan dravyaprayoga, Virechan.

The effect of the therapy was assessed by a specially prepared proforma and at the end of the treatment, 39.39\% improvement was observed in the overall effect of therapy. Paired t-test was applied to this BT and AT scores as these grades is accepted as per international norms. It showed that administered therapy reduced the degree of disease activity significantly as $\mathrm{P}<0.001$.

Key Words: Ama, Amavata, Rasnadikashayam, Sahachradikashayam, Amvatari Ras, Gandharvahastadi Erand tail, Swedan, Vata, Rheumatoid arthritis, Clinical trial

\section{INTRODUCTION}

Amavata is the disease of Madhyam Rogmarga as the Marma, Asthi and the Sandhi are the chief site of presentation of cardinal symptoms like Sandhishool, Sandhigrah and Sandhishoth.$^{1}$ At present, people are again getting attracted to, an ancient system of healing, 'Ayurveda'; as it rectifies disease along with, lifestyle originated consequences. In this present world of hurry, worry and curry, the occurrence of diseases caused by faulty lifestyle is increasing day by day and Amavata is one of those diseases. Amavata having two predominant pathological factors Ama and Vata from which Ama is formed due to Mandagni along with vitiated vata moves towards Sleshmasthana including joints then it undergoes Sthanasanshraya in the Sandhis and causes severe pain. $^{2}$ It is an inflammatory joint disease, mainly affecting the middle age group. It is characterized by swelling, pain, morning stiffness, local temperature, etc. affecting large joints of extremities. It is a debilitating disease in view of its chronicity and complications. Therefore, it has taken the foremost place among the joint disorders. It can be compared with Rheumatoid arthritis, an autoimmune disorder.

\section{Corresponding Author:}

Dr. Sonali Dilip Wairagade, Associate Professor, Department of Kayachikitsa, Datta Meghe Ayurved Medical College Hospital and Research Centre, Wanadongri, Nagpur, Maharashtra, India; Mobile: 9822644614; Email: sonaliwairagade@gmail.com

ISSN: 2231-2196 (Print)

Received: 18.05 .2020
ISSN: 0975-5241 (Online)

Revised: 15.06 .2020
Accepted: 05.07.2020 
Rheumatoid Arthritis is the most common inflammatory arthritis which mainly affects the synovial joints. ${ }^{3}$ The typical clinical feature of Rheumatoid Arthritis is the deforming of symmetrically small and large joints polyarthritis some patients present with the mild disease having less joint damage and in others, it is most severe. RA occurs throughout the world in all races, females are three times more prone to this disease than males, the onset of the disease increases as the age advances. ${ }^{4}$ When there is the predominance of Pitta dosha along with Ama and Vata then inflammatory signs like Raga (redness) and Daha (burning sensation) are observed and heaviness and itching in affected part after the involvement of Kaphadosha. ${ }^{5}$ The Apathy Ahara and Vihara mentioned in Hetu of Amavata leads to Doshprakopa and Amavastha simultaneously or one after other. ${ }^{6}$ The Ama so formed is distributed due to vitiated Vata along with other Doshas to Sleshmasthanaand leads to Amavata?

According to Ayurveda; agni is the basic pillar of our life as it converts food in the form of energy with the help of which all vital functions are carried out in our body. ${ }^{8}$ Agni is the cause of Oja, strength, Bala, Varna, and Prana. ${ }^{9}$ Ama is toxic, sticky, thick, foul-smelling, undigested food in the body. Ama lines the wall of the bowel and impaired the assimilation and absorption of nutrients. ${ }^{10}$

Allopathic medicines do give symptomatic relief instantly in Amavata, but their prolonged use is certainly not advisable due to severe side effects. Also, those medicines do not cure the disease from the root. So the world is finding an answer to this disease from Ayurveda. In Ayurveda, Amavata was first described separately by Madhava Nidana. 'Ama' is an entity, produced from the indigestion of food. This ' $A m a$ ' is taken along with vitiated 'Vata' to 'Shleshma Sthanas' including Hridaya, Sandhis, etc. and Amavata is produced. ${ }^{11}$ So the management of Amavata focuses on improving the digestion of food, 'Pachana', and also the 'Pachana' of Ama Rasa Dhatu developed in etiopathogenesis.

According to Yogaratnakara, the main concept of Chikitsa of Amavata consists of Langhana, Svedana, Deepana, intake of Katu, Tikta Rasas, Virechana, Basti, RukshaSveda, as per Avastha of Vyadhi.

Chakradatta firstly mentioned the treatment of Amavata. Management of Amavata mainly includes 1. Langhana 2. Shamana Chikitsa 3. Shodhana Chikitsa. As Amavata is Rasa dushtijanya disease Langhana is the best first line of treatment for the digestion of Ama and increasing metabolic power. ${ }^{12}$ Thus, by using Ayurvedic formulations to 15 patients helps to expel out the morbid Doshas from the body and thereby giving relief in the disease. Thought in the mind is to evaluate the efficacy of these Ayurvedic formulations in the management of Amavata. Hence a research work entitled"Efficacy of Ayurvedic Formulations along with Swedan Therapy in the Management of Amavata (Rheumatoid
Arthritis)-A Clinical Study" was conducted at Datta Meghe Ayurved Medical College Hospital \& Research Centre.

\section{AIMS AND OBJECTIVES:}

Aim:

To evaluate the utility and efficacy of Ayurvedic formulations (Rasnadikashayam, Sahachradikashayam, Amvatari Ras, Erand tail along with ruksh Swedan) in the management of Amvata (Rheumatoid arthritis).

\section{Objectives:}

1. To review all Ayurvedic as well as modern literature regarding Amavata

2. To study the Samprapti of Amavata and its management

3. To evaluate the efficacy of Ayurvedic formulations in Amavata

4. To reveal the probable action of Ayurvedic formulations (Rasnadikashayam, Sahachradikashayam, Amvatari Ras, Erand tail along with ruksh Swedan) in the management of Amavata

\section{MATERIAL AND METHOD}

\section{A. Settings:}

A total of 15 patients of Amavata were randomly selected for the present study, from the Kayachikitsa OPD and IPD of Datta Meghe Ayurved Medical College Hospital \& Research Centre.

In the present study, total of 15 patients were registered. The case selection was random regardless of age, sex, occupation, and socio-economic conditions. Both acute and chronic phases of Amavata patients were taken for the study, following the criteria of the diagnosis of rheumatoid arthritis in Modern Medicine and the clinical features of Amavata described in Madhava Nidana.

The patients were diagnosed on the basis of American criteria of Rheumatoid Arthritis as well as signs and symptoms mentioned in the classics. American is mentioned as follows: ${ }^{13}$

1. Morning stiffness lasting for at least 1 hour and for more than 6 weeks

Arthritis of 3 or more of 14 possible joints area

2. Arthritis of hand joints, wrist, metcarpophalangeal, interphalangeal, metatarsophalangeal joints for more than 6 weeks

3. Symmetrical arthritis - Simultaneous involvement of the same joint areas

4. Rheumatoid nodules - Subcutaneous nodules over bony prominences 
5. Serum Rheumatoid factor

6. Radiological changes

\section{B. Participants:}

- Patients - Amavata (Rheumatoid arthritis)

- Gender-Both Male and Female

- Age- From 15yrs-65yrs of age.

\section{Data collection tools and process:}

Patients fulfilling inclusion criteria and willing to give written consent were enrolled for the study. The selected patients were informed about the possible outcomes and side effects of the interventional drugs.

- Criteria of inclusion:

1. All patients of any age group, sex fulfilling the American criteria for rheumatoid arthritis.

2. All patients presenting with signs and symptoms resembling Amavata

- Criteria of exclusion:

1. Patients not willing for trial

2. Patients who left the treatment in between

3. Patients who were steroid-dependent for relief of symptoms

4. Patients presenting with complications like SLE, endocarditis, etc.

5. Patients with contractures of joints will not be included

\section{Treatment Drugs:}

Therapeutic regime mentioned in Ayurvedic classics i.e., Langhana, Swedana, Use of Tikta, Katu and Deepan dravyaprayoga, Virechan, Snehapan.

\begin{tabular}{|c|c|c|c|c|c|}
\hline $\begin{array}{l}\text { Sr. } \\
\text { No. }\end{array}$ & $\begin{array}{l}\text { Treatment } \\
\text { Drugs }\end{array}$ & Dose & Timing & Duration & Anupan \\
\hline 1 & Rasnadikashayam & 3 t.s.f. & 9 a.m. & 3 months & Water \\
\hline 2 & $\begin{array}{l}\text { Sahachradikash- } \\
\text { ayam }\end{array}$ & 3 t.s.f & 9 a.m. & 3 months & Water \\
\hline 3 & Rasnadikashayam & 3 t.s.f. & 5 p.m. & 3 months & Water \\
\hline 4 & Amvatari Ras & 2 tabs & 9 p.m. & 3 months & Water \\
\hline 5 & Rasnadikashayam & 3 t.s.f. & 9 p.m. & 3 months & Water \\
\hline 6 & Erand tail & 1/2t.s.f. & 1op.m. & 1 month & Water \\
\hline 7 & Ruksha Swedan & - & 10 a.m. & 1 month & - \\
\hline
\end{tabular}

\section{Preparation of Drugs:}

Rasnadikashayam, Sahachradikashayam, Amvatari Ras, Erand tail are one of the well known therapeutic preparations described in Bhaishajya Ratnawali having very much similar gunas and action described in chikitsa sutra

\section{Rasnadikashayam: ${ }^{14}$}

Composition: Each $10 \mathrm{ml}$ is prepared out of -

\begin{tabular}{lllll}
$\begin{array}{llll}\text { Sr. } \\
\text { No. }\end{array}$ & Nanskrit & Botanical Name & $\begin{array}{l}\text { Parts } \\
\text { used }\end{array}$ & Quantity \\
\hline 1 & Rasna & Alpinia galanga & Root & 0.139 gm \\
2 & Eranda & Ricinus communis & Root & o.139 gm \\
3 & Shunti & Zingiberofficinale & Rhizome & $0.139 \mathrm{gm}$ \\
4 & Vasa & Adhatodavasica & Root & $0.139 \mathrm{gm}$ \\
5 & Sati & Curcuma zedoaria & Rhizome & $0.139 \mathrm{gm}$ \\
6 & Dusparsa & Tragiainvolucrata & Plant & $0.139 \mathrm{gm}$ \\
7 & Sahachara & Strobilanthesciliatus & Plant & $0.139 \mathrm{gm}$ \\
8 & Ativisha & Aconitum ferox & Root & $0.139 \mathrm{gm}$ \\
9 & Ghana & Cyperusrotundus & Root & $0.139 \mathrm{gm}$ \\
10 & Bala & Sidacordifolia & Root & $0.139 \mathrm{gm}$ \\
11 & Ikshura & Astercanthalongifolia & Root & $0.139 \mathrm{gm}$ \\
12 & Devadaru & Cedrusdeodara & Stem & $0.139 \mathrm{gm}$ \\
13 & Guduchi & Tinosporacordifolia & Stem & $0.139 \mathrm{gm}$ \\
14 & Shatavari & Asparagus racemosus & Root & $0.139 \mathrm{gm}$ \\
\hline
\end{tabular}

\section{Method of Preparation:}

Add eight parts of water to these herbs and boil them till the amount is reduced to $1 / 4^{\text {th }}$ part. Filter the mixture and store the filtrate in a clean container.

\section{Benefits:}

- Treats rheumatic arthritis

- Eases stiffness in joints

- Reduces general body ache

- Effective in all types of joint pain

\section{Sahachradikashayam ${ }^{15,16,17}$}

\begin{tabular}{llll}
$\begin{array}{lll}\text { Sr. } \\
\text { No }\end{array}$ & Sanskrit name & Botanical name & Quantity \\
1 & Sahachara & Barleriaprionitis & 1 Part \\
2 & Suradaru(Devadaru) & Cedrusdeodara & 1 Part \\
3 & Shunti & Zingiberoffcianlis & 1 Part \\
\hline
\end{tabular}

\section{Method of Preparation:}

Herbal ingredients (coarse powder) 1 part were boiled in 16 parts of water and reduced to 4 parts.

Method of Storage: Stored in airtight container in dry place

\section{Ayurvedic Properties of Sahacharadi Kashayam:}

- Roga karma: Useful in Vatarogas.

- Dosha karma: Kaphavatahara.

- Agni karma: Pachana and deepana. 


\section{AmvatariRas ${ }^{18}$}

\begin{tabular}{llll}
$\begin{array}{l}\text { Sr. } \\
\text { No. }\end{array}$ & Sanskrit Name & Quantity \\
& \multicolumn{3}{c}{ Chemical/Botanical } \\
Name & \\
1 & Parada & Mercury & 1 Part \\
2 & Gandhaka & Sulphur & 2 Parts \\
3 & Hirda & Terminalia chebula & 1 Part \\
4 & Beheda & Terminalia bellirica & 1 Part \\
5 & Amalki & Phyllanthus emblica & 1 Part \\
6 & Chitrak & Plumbago zeylanica & 4 Parts \\
7 & Guggulu & Commiphorawightii & 5 Parts \\
8 & Eranda & Ricinus communis & Bhavana \\
& & & Dravya \\
\hline
\end{tabular}

\section{Method of Preparation of Amavatari rasa:}

Process: 1 part of shuddha Parada was added with 2 parts of shuddha Gandhaka and Kajjali was prepared by triturating in a khalwa. 5 parts of guggulu was taken into a khalwa and it was pounded well by adding kajjali and 3 parts of Triphala, 4 parts of Chitraka. During the process, Erandataila of required amount was added and pounding was continued until a soft homogeneous mass formed. This soft mass was passed through a pill cutter to prepare the desired size of tablets (500 mg each). The prepared tablets were stored in well-closed glass containers.

\section{Erandtail ${ }^{19,20,21,22}$}

Castor oil is a vegetable oil pressed from beans. ${ }^{1}$ Castor oil is a colorless to very pale yellow liquid with a distinct taste and odor.

Erand tail is established as highly effective in treatment of rheumatoid arthritis. Bhavpraksh, Madanpal and Kaidevnighantu indicated Erand tail in Amavata.

\section{Probable mode of action of Eranda Sneha-}

- Eranda Sneha due to its Sukshma Guma ${ }^{5}$ penetrate into microchannels and remove obstruction in them ${ }^{6}$

- also due to Katu Rasa and Ushna Virya it potentiates digestive fire, acts as Vata Shamaka due to its Snigdha Guna,

- Finally, it enters at Dhatu level (cellular level) where it acts as Ama Pachaka and Kapha Shamaka drug.

\section{Ruksha Swedana. ${ }^{23}$}

Swedan was done by Valukasweda on the local parts involved.

In this, the bolus is prepared of sand. This is a typical Rooksha Sweda indicated in Amavata, Vatarakta, and Urastamb$h a$, etc. Here, the sand can be fried in Dhanyamla along with Saindhava Lavana. Much care should be taken in testing the heat of the bolus and only moderate heat should be applied.
In the below presentation of some text with specific actions related to management -

Rukshaswedan: Chakradutta, Yogaratnakar, Banga Sen, Bhaisajyaratnavali of amavata- Baluka Swedan: Chakradutta, Yogaratnakar, Banga Sen

Stambha, gaurava and shula these are the predominant features of Amavata - swedana gives good result in this condition. Swedana helps to liquefy vitiated doshas and promotes doshagati.

Patients were selected after fulfilling the criteria; and were briefed about the intended procedure. They were asked to sit comfortably over a stool of knee height.

\section{Materials required:}

- Clean sand around 300 gms

- Cloth (18 inches length and breadth)

- Thread (2 meter)

- Frying pan and Stove.

\section{Procedure:}

- The sand of medium-sized particles around 300gms taken and removed stones and soils from it.

- Sieved it well to make it clean properly.

- Heated the sand using a frying pan. Later 2 Pottalis were made with this sand.

- Pottalis were used alternatively to give Swedana over affected joints. The temperature should be sustainable for the patient. Overheating of Pottali was avoided as it may cause rupture of Pottali, so thick cloth should be used. The procedure was done by pressing, rubbing, and keeping over the said body parts.

\section{Treatment schedule -}

$\checkmark$ Langhan Therapy - light meal

$\checkmark$ Swedan was done by Valukasweda on the local parts involved.

$\checkmark$ Snehana (Internal Snehana) was used from day 8th day to 15 th for the purpose of internal snehana and virechana. For this purpose Erandataila (1/2 t.s.f.) was given with the lukewarm water at bedtime.

$\checkmark$ The trial drug was given i.e. Rasnadikashayam, Sahachradikashayam, Amvatari Ras, in the above-mentioned doses till the completion of three follow-ups (90 days).

\section{E. Assessment Criteria:}

The signs and symptoms were assessed by adopting the suitable scoring method and objective signs by using appropriate clinical tools.

Angmarda, Alasya, Gauravata, Agnimandya, Shotha (Swelling), Morning stiffness, Tenderness, Pain were graded as follow: 
Clinical assessment of the disease, its severity, extent, and grades of inflammation were objectively done in terms of pain, swelling, tenderness, deformity, general function capacity, and stiffness of the joints. The relative extent of all these criteria was recorded according to the rating scales in each patient at the initial stage and at subsequent follow-ups. These are measured by a simple count of clinically active joints.

\section{Pain}

It is determined by the intensity of pain on passive movement and the rate of analgesic drug requirement.

0 No pain

1 Pain complaints but tolerable

2 Pain complaints difficult to tolerate and taking analgesic once a day

3 Intolerable pain and taking analgesics two times a day

4 Intolerable pain and taking analgesics more than two times in a day.

\section{Swelling}

$0 \quad$ No swelling

1 Feeling of swelling + Heaviness

2 Apparent swelling

3 Huge (Synovial effusion) swelling

\section{Stiffness}

0 No stiffness

$120 \%$ limitation of normal range of mobility

$250 \%$ limitation of mobility

$375 \%$ or more reduction of normal range of movement

\section{General Function Capacity}

0 Complete ability to carry on all routine duties

1 Frequent normal activity despite slight difficulty in joint movement

2 Few activities are persisting but patient can take care of him or herself

3 Few activities are persisting patient requires an attendant to take care him/herself

4 Patient is totally bedridden

\section{Tenderness}

0 No tenderness

1 Mild tenderness

2 Moderate tenderness

3 Severe tenderness

Subjective and Objective parameters of Amavata were recorded before and after the treatment.

Data regarding above said parameters were collected:

- Before treatment, day '0'

- On $30^{\text {th }}$ day

- On $60^{\text {th }}$ day

- On $90^{\text {th }}$ day of follow up

\section{F. LABORATORYPROFILE}

For the purpose of diagnosis of disease its assessment, severity, clinical improvement, and to assess the possible side effects, certain routine, and specific investigations were performed in every patient viz.

\section{- Hematological investigations:}

Every patient was investigated for the complete haemogram. The following methods were adopted for the purpose.

(a) Total leucocytes count: This was done with the help of an improved Neubaur's hemocytometer and was recorded in the unit of per cubic millimeter.

(b) Differential leucocytes count: This was done with the help of thin blood smear prepared with Leishman's staining.

(c) Hemoglobin: Estimation of Hemoglobin in blood was done with Sahlis haemoglobinometer recorded in gm $\%$ unit.

(d) Erythrocyte Sedimentation Rate: This was done by the Wintrobes method and recorded in $\mathrm{mm} / \mathrm{hr}$ unit for the first hour.

\section{- Biochemical: C - reactive protein (C-RPtiter)}

This was done by the method of qualitative and semi-quantitative latex fixation slide test. The test was based on the immunologic reactions between CRP as an antigen and Latex particle counted with nonspecific anti-human CRP and sensitized to detect levels greater than six (6) micrograms per milliliter $(0.6 \mathrm{mg} / \mathrm{dl})$.

\section{- Rheumatoid factor (RA titer)}

In rheumatoid arthritis (R.A.), diagnostically useful auto antibodies termed as a rheumatoid factor can be detected which are immunoglobulin of the class IgG, IgM, IgA and IgE, IgM class RF with specificity to human IgG Fc is the most prognostic marker for RA. RF plays a role in perpetuating the rheumatoid inflammatory process; the severity of joint damage could be predicted according to the strength of RF reactivity. A significant decline of RF with remission of disease activity has also been demonstrated. Therefore, quantified serial determinations of RF are more meaningful in the diagnosis, prognosis, and assessment of therapeutic efficacy of rheumatoid arthritis.

\section{Degree of disease Activity:}

For diagnostic and therapeutic purposes, the degree of disease activity was estimated on the basis of criteria laid down by the American Rheumatism Association (1967). Details are given in the Table. In these criteria, the maximum score is 27 , which represents an average grade of 3 (severely active). By dividing the total score by 9 , the grade of the disease was obtained and denoted by grades zero (0) to three (3). The table is described here: 
Table 1: Table Showing Semi Quantitative Criteria of Estimating of Degree of Disease Activity

\begin{tabular}{|c|c|c|c|c|}
\hline Grade & $\mathbf{o}$ & $\mathbf{1}$ & 2 & 3 \\
\hline Morning stiffness & $\begin{array}{l}\text { No morning stiff- } \\
\text { ness }\end{array}$ & $\begin{array}{l}\text { Morning stiffness }>1 / 2 \mathrm{hr} \text { but } \\
<1 \mathrm{hr}\end{array}$ & $>$ lhr but $<6 \mathrm{hr}$ & All the day through \\
\hline Fatigue & None & $\begin{array}{l}\text { Work fulltime despite some } \\
\text { fatigue }\end{array}$ & $\begin{array}{l}\text { Patient must interrupt } \\
\text { work to take rest }\end{array}$ & Fatigue at rest \\
\hline Pain & None & $\begin{array}{l}\text { Mild pain of low intensity not } \\
\text { disturbing routine work }\end{array}$ & $\begin{array}{l}\text { Moderate pain ham- } \\
\text { pers daily routine work }\end{array}$ & $\begin{array}{l}\text { Severe pain causing } \\
\text { definite interruption } \\
\text { in routine work }\end{array}$ \\
\hline General function & $\begin{array}{l}\text { All activities with- } \\
\text { out difficulty }\end{array}$ & $\begin{array}{l}\text { Most activities but with dif- } \\
\text { ficulty }\end{array}$ & $\begin{array}{l}\text { Few activities } \\
\text { Care for self }\end{array}$ & $\begin{array}{l}\text { Little self care mainly } \\
\text { chair \& bed ridden }\end{array}$ \\
\hline Spread in joints & None & o to 5 & 5 to 10 & More than 10 \\
\hline ESR & $0-20$ & $20-40$ & $40-6 o$ & $>60$ \\
\hline $\mathrm{Hb} \mathrm{gm} \%$ & $>12$ & $12-10$ & $10-9$ & $<9$ \\
\hline Physicians estimate & Inactive & Minimum & Moderately Active & Severely Active \\
\hline Patients estimate & Fine & Almost well & Pretty good & Pretty bad \\
\hline
\end{tabular}

Table 2: Table Showing Age-Wise Distribution of 15 Patients of Amavata

\begin{tabular}{lccc} 
Sr. No. & Age Group & No. of Patients & Percentage \\
1 & $15-20$ & 1 & 6.66 \\
2 & $20-25$ & 0 & 0 \\
3 & $25-30$ & 3 & 20 \\
4 & $30-35$ & 2 & $13 \cdot 33$ \\
5 & $35-40$ & 3 & 20 \\
6 & $40-45$ & 1 & 6.66 \\
7 & $45-50$ & 2 & 13.33 \\
8 & $50-55$ & 0 & 0 \\
10 & $55-60$ & 2 & $13 \cdot 33$ \\
\hline
\end{tabular}

Table 3: Table Showing Sex-Wise Distribution Of 15 Patients Of Amavata

\begin{tabular}{llcc} 
Sr. No. & Sex & No. of Patients & Percentage \\
1 & Male & 4 & 26.67 \\
2 & Female & 11 & 73.33 \\
\hline
\end{tabular}

Table 4: Table Showing Religion wise Distribution of 15 Patients of Amavata

\begin{tabular}{llcc} 
Sr. No. & Religion & No.of patients & Percentage \\
1 & Hindu & 11 & 73.33 \\
2 & Muslim & 1 & 6.66 \\
3 & Buddha & 3 & 10 \\
\hline
\end{tabular}

Table 5: Table Showing Socio Economic Status Of 15 Patients Of Amavata

\begin{tabular}{lllr} 
Sr. No. & Economical Status & No. of Patients & Percentage \\
1 & Poor & 6 & 40 \\
2 & Middle & 7 & 46.66 \\
3 & Rich & 2 & 13.33 \\
\hline
\end{tabular}


Table 6: Table Showing Physical Built-wise Distribution Of 15 Patients Of Amavata

\begin{tabular}{llcc} 
Sr. No. & Physical Built & No. of Patients & Percentage \\
1 & Krisha & 8 & $53 \cdot 33$ \\
2 & Madhyama & 4 & 26.66 \\
3 & Sthoola & 3 & 20 \\
\hline
\end{tabular}

Table 7: Table Showing Effect of Treatment on Signs and Symptoms of 15 Patients Of Amavata

\begin{tabular}{llcccc} 
Sr. No. & Sign/Symptom & BT & Symptom score & Difference & \% of relief \\
1 & AngAmarda & 40 & 18 & 22 & 55 \\
2 & Alasya & 42 & 22 & 20 & 47.62 \\
3 & Gauravata & 38 & 17 & 21 & 55.26 \\
4 & Agnimandya & 45 & 24 & 21 & 46.66 \\
5 & Swelling & 48 & 39 & 9 & 18.75 \\
6 & Morning Stiffness & 50 & 37 & 13 & 26 \\
7 & Tenderness & 54 & 36 & 18 & 33.33 \\
8 & Pain & 46 & 27 & 19 & 41.3 \\
& Total & 363 & 220 & 143 & 39.39 \\
\hline
\end{tabular}

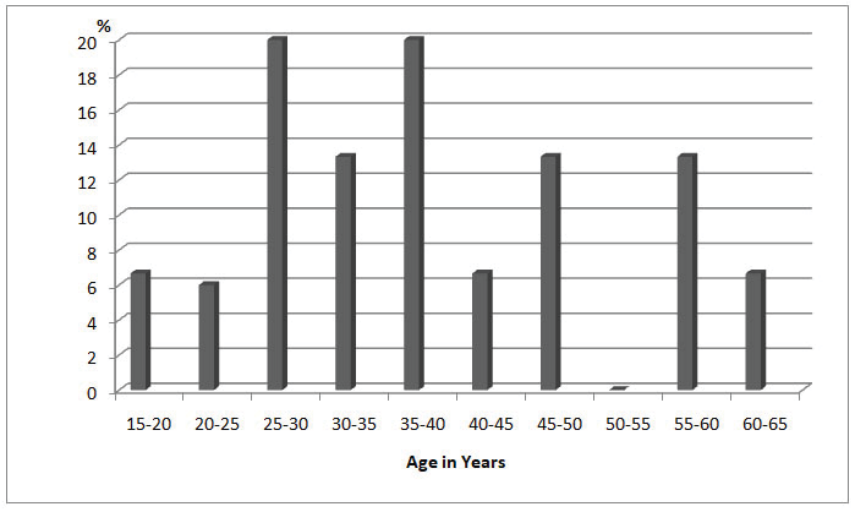

Graph A: Distribution according to Age wise status.

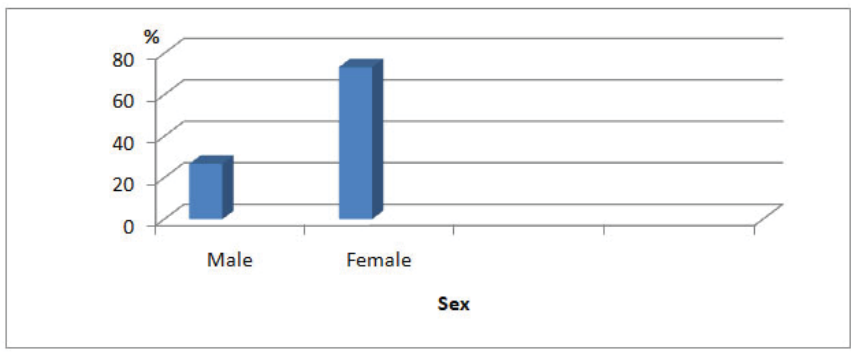

Graph B: Distribution according to Sex wise status.

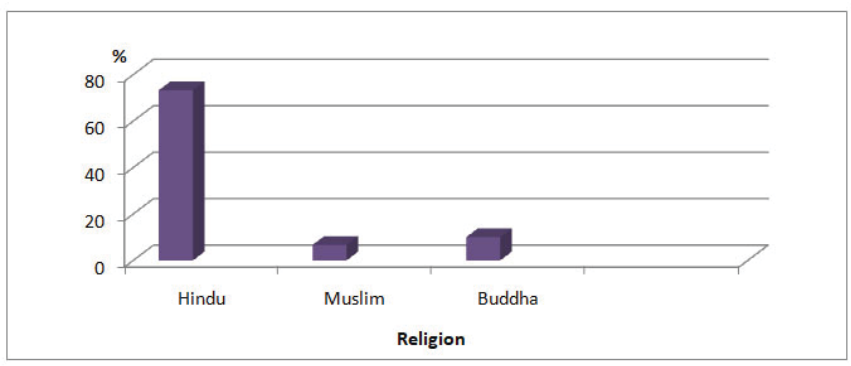

Graph C: Distribution according to religion wise status.

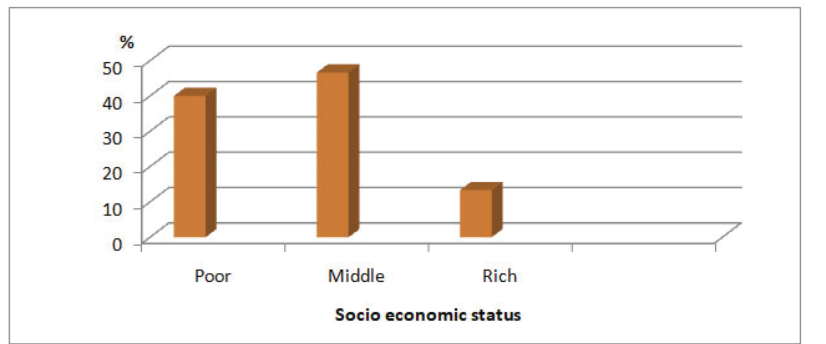

Graph D: Distribution according to Socio-economic wise status:

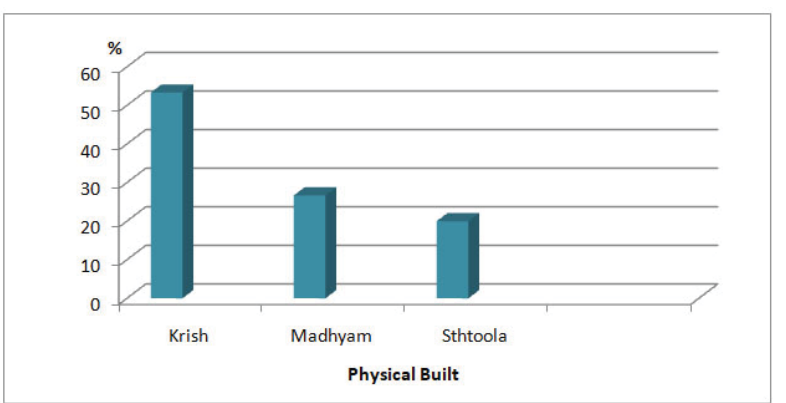

Graph E: Distribution according to Physical built wise status:

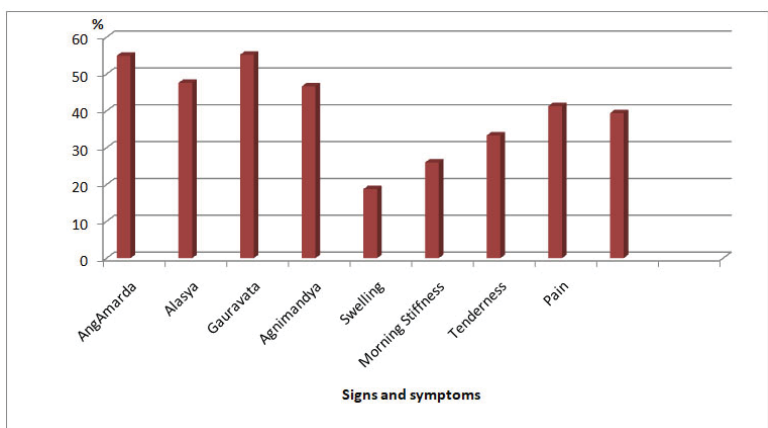

Graph F: Distribution according to relief in signs and symptoms wise. 
Table 8: Table Showing Effect of Therapy on Haematologiacal Parameters of 15 Patients of Amavata By Paired t Test

\begin{tabular}{lllrrrrr} 
Sr. No. & $\begin{array}{l}\text { Haematological } \\
\text { parameters }\end{array}$ & \multicolumn{2}{c}{ Mean \pm SD } & Mean of Diff. \pm SD & SEd & T & P \\
& Haemoglobin & $11.3 \pm 1.0925$ & $12.34 \pm 0.786$ & $1.04 \pm 0.8567$ & 0.1916 & 5.425 & $<0.001$ \\
2 & ESR & $54.6 \pm 5.566$ & $45.15 \pm 7.035$ & $9.45 \pm 5.394$ & 1.206 & 7.830 & $<0.001$ \\
\hline
\end{tabular}

\begin{tabular}{|c|c|c|c|c|c|c|c|}
\hline \multirow{2}{*}{$\begin{array}{l}\text { Sr. } \\
\text { No }\end{array}$} & \multirow{2}{*}{ Parameters } & \multicolumn{2}{|c|}{ Mean \pm SD } & \multirow[t]{2}{*}{ Mean of Diff. \pm SD } & \multirow[t]{2}{*}{ SEd } & \multirow[t]{2}{*}{$\mathbf{T}$} & \multirow[t]{2}{*}{$\mathbf{P}$} \\
\hline & & BT & AT & & & & \\
\hline 1 & Morning stiffness & $2.05 \pm 0.223$ & $0.8 \pm 0.523$ & $1.25 \pm 0.444$ & 0.099 & 12.57 & $<0.001$ \\
\hline 2 & Fatigue & $1.8 \pm 0.523$ & $0.7 \pm 0.571$ & $1.1 \pm 0.307$ & 0.0688 & $15 \cdot 97$ & $<0.001$ \\
\hline 3 & Pain & $1.9 \pm 0.447$ & $0.95 \pm 0.394$ & $0.95 \pm 0.2236$ & 0.050 & 18.99 & $<0.001$ \\
\hline 4 & General function & $1.85 \pm 0.366$ & $0.9 \pm 0.447$ & $0.95 \pm 2236$ & 0.050 & 18.99 & $<0.001$ \\
\hline 5 & Spread in joints & $1.1 \pm 0.3077$ & $0.95 \pm 0.2236$ & $0.15 \pm 0.366$ & 0.0819 & 1.830 & $>0.05$ \\
\hline 6 & $\mathrm{Hb}$ gm $\%$ & $0.95 \pm 0.510$ & $0.45 \pm 0.510$ & $0.5 \pm 0.512$ & 0.1147 & $4 \cdot 356$ & $<0.02$ \\
\hline 7 & ESR & $2.1 \pm 0.0377$ & $1.74 \pm 0.444$ & $0.35 \pm 0.489$ & 0.1094 & 3.197 & $<0.02$ \\
\hline 8 & Physicians estimate & $2.0 \pm 0.3244$ & $0.95 \pm 0.223$ & $1.05 \pm 0.2236$ & 0.050 & 20.98 & $<0.001$ \\
\hline 9 & Patients estimate & $2.05 \pm 0.2336$ & $0.95 \pm 0.2336$ & $1.1 \pm 0.3077$ & 0.0688 & 15.975 & $<0.001$ \\
\hline \multicolumn{2}{|c|}{ Total disease activity } & $1.78 \pm 0.2142$ & $0.945 \pm 0.2416$ & $0.835 \pm 0.0812$ & 0.0181 & 45.92 & $<0.001$ \\
\hline
\end{tabular}

\section{Observations and Results:}

All the patients of Amavata of this series were examined in detail with respect to the special proforma.

Most of the patients (60\%) of this series were male (Table-2). $20 \%$ were of age group 25 to 30 years (Table-1). $73.33 \%$ of the patients from were Hindu religion (Table-3). Most of the patients $(46.66 \%)$ were from middle economic status (Table-4). $53.33 \%$ of patients were Krisha in physical built (Table-5).

Before starting the treatment, symptoms present in all patients were graded and their values were noted before treatment (BT). After completion of treatment, they were noted after treatment (AT). The data was assessed as a percent of relief as shown in Table-6.

$55.26 \%$ relief was observed in Gauravata while 47.62 reliefs were seen in Alasya. The swelling was relieved by $18.75 \%$ only; while $41.3 \%$ relief was observed in Pain. The average percentage relief was $39.39 \%$. It was observed that $\mathrm{Hb}$ $\mathrm{gm} \%$ Mean $\pm \mathrm{SD}$ was $11.3 \pm 1.0925$ before treatment which was increased to $12.34 \pm 0.786$ which is highly significant as $\mathrm{P}<0.001$. The paired t-test was also applied to ESR, which was $54.6 \pm 5.566$ before treatment, was reduced to 45.15 \pm 7.035 ; this is highly significant as $\mathrm{P}<0.001$. It was observed that morning stiffness, fatigue, pain, general functions, $\mathrm{Hb}$ gm\%, ESR, physician estimate, and patient's esti- mate showed significant progress. The average of all criteria of the degree of disease activity before treatment was $1.78 \pm$ 0.2142 which was reduced to $0.945 \pm 0.2416$. The paired ttest was applied to this BT and AT scores as these grades are accepted as per international norms.

It showed that administered therapy reduced the degree of disease activity significantly as $\mathrm{P}<0.001$.

\section{DISCUSSION}

Amavata is a commonest inflammatory joint disease, because of which patient's life becomes miserable, patients are crippled. No effective remedies are available so far in modern science or other streams of medical science. In patients suffering from Amavata, Ayurveda has a definite role to manage the disease with Deepana, Pachana, and Ruksha Swedan in this study patient suffering from Amavata had an average of $39.39 \%$ of relief.

While the maximum percentage of relief $55.26 \%$ was noted in Gauravata while Shotha was relieved by $18.75 \%$. It was observed that $\mathrm{Hb}$ gm\% Mean $\pm \mathrm{SD}$ was $11.3 \pm 1.0925$ before treatment which was increased to $12.34 \pm 0.786$ which is highly significant as $\mathrm{P}<0.001$. The paired t-test was also applied to ESR, which was $54.6 \pm 5.566$ before treatment, was reduced to $45.15 \pm 7.035$; this is highly significant as 
$\mathrm{P}<0.001$. It was observed that morning stiffness, fatigue, pain, general functions, $\mathrm{Hb}$ gm $\%$, ESR, physician estimate, and patient's estimate showed significant progress. The average of all criteria of the degree of disease activity before treatment was $1.78 \pm 0.2142$ which was reduced to 0.945 \pm 0.2416 . The paired t-test was applied to this BT and AT scores as these grades is accepted as per international norms. It showed that administered therapy reduced the degree of disease activity significantly as $\mathrm{P}<0.001$.

\section{CONCLUSION}

It is very obvious from the aforesaid observation and results that Ayurvedic Formulations along with Ruksha Swedan therapy had a beneficial effect in only 11days. Patients were relieved up to a certain extent from their sufferings. This management was not much costlier or did not show any side effects. The drug mentioned in Ayurveda in the management of Amavata gives the promising results and cure the disease by eliminating the root cause of the disease which cannot be achieved with the help of modern medicines. It is very obvious from this study that Ayurvedic concept of management of Amavata plays a major role in the present era to serve mankind. Also, it is observed that along with this line of treatment, when Rasayana Drugs like Amrit Bhallataka Avleha, Bhallataka Kshirpaka are administered to patients, they improve digestion and immunity as well; thus are useful in the management of Amavata.

Acknowledgement: Authors acknowledge the immense help received from Datta Meghe Ayurvedic Medical College Hospital \& Research Center, Wanadongri, Nagpur for conducting this study.

\section{Conflict of interest: None}

\section{REFERENCES}

1. Shri Shastri Sudarshan, Madhavnidanam Purvardha, Amvatnidanamadhyaya 25/1-5, edition reprint, published by Chaukhamba Sanskrit Sansthan Varanasi, 2010; 511.

2. Shri Shastri Sudarshan, Madhavnidanam Purvardha, Amvatnidanamadhyaya 25/1-5, edition reprint, published by Chaukhamba Sanskrit Sansthan Varanasi, 2010; 509.

3. Current Medical Diagnosis and Treatment, Mc. Graw Hill, forty seventh Edition, 2008; 721.

4. Davidson's principles and practice of medicine, chapter 20 musculoskeletal disorder, 19th edition Churchill Livingstone publication, 2002; 1002.

5. Upadhyay Y., Madhav Nidan Madhukoshvyakhya, Amavatanidanam, ch 25, edition reprint, published by- Chaukhamba Sanskrit Sansthan Varanasi, 2003; 512.
6. Shri Shastri Sudarshan, MadhavnidanamPurvardha, Amvatnidanamadhyaya 25/1-5, edition reprint, published by Chaukhamba Sanskrit Sansthan Varanasi, 2010; 509

7. Shri Shastri Sudarshan, Madhavnidanam Purvardha, Amvatnidanamadhyaya 25/1-5, edition reprint, published by Chaukhamba Sanskrit Sansthan Varanasi, 2010; 509. Milind et al. World Journal of Pharmacy and Pharmaceutical Sciences www.wjpps.com Vol 7, Issue 10, 2018. 1769

8. Tripathi Ravi Dutt, Ashtang Samgraha of srimad Vridhavagbhata, edited with Saroj hindi commentary, sutrasthana chapter 9/36, edition reprint, published by- Chaukhamba Sanskrit Pratishthan Varanasi, 2005; 195.

9. Acharya Vidyadhar Shukla, Ravi Dutt Tripathi- Chrak Samhita vol 2 edited with 'Vaidya manorama' hindi commentary, chikitsasthan chapter $15 / 4$, edition reprint, published by- Chaukhamba Sanskrit sansthan Varanasi, 2013; 358.

10. Banwari Lal Gaud, Ashtang Hridyamsamvartika, Hindi commentary, chapter $13 / 25-27$, reprint published by Chukhambaorientalia, Varanasi, 2007; 237.

11. Shri Shastri Sudarshan, Madhavnidanam Purvardha, Amvatnidanamadhyaya 25/1-5, edition reprint, published by Chaukhamba Sanskrit Sansthan Varanasi, 2010; 509.

12. Banwari Lal Gaud, Ashtang Hridyamsamvartika, Hindi commentary, chapter $13 / 25-27$, reprint published by Chukhambaorientalia, Varanasi, 2007; 153.

13. Arnett FC, Edworthy SM, Bloch DA, McShane DJ, Fries JF, Cooper NS et al. (1988) The American Rheumatism Association 1987 revised criteria for the classification of rheumatoid arthritis. Arthritis Rheum 31:315-324

14. Sivarajan VV, Balachandran I. Ayurvedic Drugs and their Plant Sources. New Delhi: Oxford and IBH Publishing Co. Pvt. Ltd; (1999).

15. Krishna KPR. The efficacy of Ayurvedic treatment for rheumatoid arthritis: cross sectional experimental profile of a longitudinal analysis. Int J Ayurveda Res. 2011;2:8-13.

16. Macfarlane GJ, El-Metwally A, De Silva V, Ernst E, Gillian L, Dowds GL, Moots RJ. Rheumatology (Oxford). 2011;50:167283.

17. Pushpan R, Nishteswar K, Kumari H. Anti-arthritic natural medicine: Classical Ayurvedic and ethnomedical sources. ASL Muscuskel Dis. 2013;1:32-40.

18. Govindadassen, Mishra S. N. Bhaishaijya Ratnavali with Siddhiprada Hindi Commentary. 1st edition. Varanasi; Chaukhambha Surabharati Prakashan; 2005.

19. Thomas, Alfred (2005). "Fats and Fatty Oils". Ullmann's Encyclopedia of Industrial Chemistry. Weinheim: WileyVCH. doi:10.1002/14356007.a10_173. ISBN 978-3527306732.

20. Chuneker K.C. (Ed.). Bhavaprakasa Nighantu. Varanasi, Chaukhambha Bharti Academy, 2010; 286-288.

21. Shastry, J.L.N. (Ed.) Madanpal Nighantu. Varansi, Chaukhamba Orientalia, 65.

22. Sharma P.V. and Sharma G.P (Ed.). Kaideva Nighantu. Varansi, Chaukhamba Orientalia, 2006; 24-25.

23. Keraleeya Chikitsakrama (Malayalam) chapter 2. Trivandrum: Vasudevavalasam Publications; 1982. P.6. 